Jap. J. M. Sc. \& Biol., 9, 113-116, 1956

\title{
RADIOACTIVITY OF HUMAN ORGANS ${ }^{1)}$
}

\author{
YASUYUKI EGASHIRA ${ }^{2)}$ AND TAKESHIge SAKURABAYASHI ${ }^{3}$ ) \\ Department of Pathology, National Institute of Health, Tokyo4)
}

(Received: June 25th, 1956)

The radioactivity of organs would have often to be measured at autopsy in the near future as the utilization of atomic energy advances. On such occasions, it is necessary to compare the values then obtained with the standard or so-called normal values of radioactivity of human organs. But, there are no data available that should become the basis of comparison.

The radioactivity of various organs was measured on the autopsy cases of sudden death by such causes as acute heart diseases, intracranial haemorrhage and acute poisoning.

Since there is a certain amount of potassium in the human body and potassium contains the natural radioactive potassium at the rate of $0.01-0.012 \%$, it was also studied that whether the activity shown by $\mathrm{G}-\mathrm{M}$ counter is contributed to the natural radioactive potassium. In order to determine the potassium content, some samples of the same materials was sent to Mr. Ohtsu of Kanto Communication Hospital (See the next report).

\section{MATERIALs AND MethodS}

Materials: Livers, lungs, hearts, spleens, kidneys and brains of the autopsy cases5) of sudden death during July 1954 and January 1955 were used. The number of organs obtained was diversed from 21 to 13 depending upon organs. The autopsy cases here dealt with include 8 cases of acute heart diseases, 5 of acute poisoning (not including those by potassium compounds), 3 of acute intracranial diseases and of asphyxia respectively and 2 of other causes. The age of the deceased extends from 12 to 77 years of age, and 12 cases of them are within the range between 21 and 50 years of age.

Methods for measurement of radioactivity: All utensils used were treated with "Desicote". The weight of organs was measured, cut into pieces, then dried at $100^{\circ} \mathrm{C}$ for 3-4 days, and carbonized for about 4 hours by heat adding with 5-10 cc of fuming nitric acid, and then reduced to ashes at $500^{\circ} \mathrm{C}$ for about 10 hours and weighed. The

1) The content was reported at the 44th General Meeting of the Japanese Pathological Society in April, 1955 and was abstracted in Tr. Soc. Path. Jap., 44, 195, 1955.

2)江頭靖之・3)桜林武成, 4)国立予防衛生研究所病理部

5) The organs were offered by the courtesy of the Tokyo-to Medical Examiner's Office. 
Table 1. Radioactivity

\begin{tabular}{|c|c|c|c|c|}
\hline $\begin{array}{l}\text { Autopsy } \\
\text { number }\end{array}$ & Age & $\& \operatorname{sex}$ & Cause of death & Spleen \\
\hline 11021 & 16 & $\delta$ & $\begin{array}{l}\text { Death of sleeping draught (Bromvaleryl- } \\
\text { urea) }\end{array}$ & - \\
\hline 11022 & 19 & $\hat{\delta}$ & Death of sleeping draught (Barbiturate) & $6.8 \pm 1.1$ \\
\hline 11065 & 22 & $\delta$ & Acute heart failure & $5.5 \pm 1.0$ \\
\hline 11068 & 48 & $\delta$ & Death of drowning & $7.3 \pm 1.3$ \\
\hline 11451 & 27 & $\delta$ & Death of sleeping draught (Barbiturate) & $6.3 \pm 1.1$ \\
\hline 11453 & 42 & $\delta$ & Hemorrhage in pons & $5.9 \pm 0.7$ \\
\hline 11454 & 68 & $\delta$ & Acute heart failure & $6.7 \pm 0.6$ \\
\hline 11546 & 58 & $\delta$ & Heart rupture & - \\
\hline 11549 & 49 & $\delta$ & Acute heart failure & $4.4 \pm 0.5$ \\
\hline 11614 & 29 & $\delta$ & Acute heart failure & $5.4 \pm 0.5$ \\
\hline 11615 & 14 & 우 & Death of strangulation & $11.4 \pm 3.1$ \\
\hline 11616 & 12 & $\delta$ & Death of strangulation & $6.4 \pm 0.5$ \\
\hline 11935 & 24 & $\delta$ & Asphyxia (by aspiration of vomited mass) & $5.6 \pm 0.6$ \\
\hline 11937 & 77 & 우 & Acute heart failure & $7.3 \pm 1.3$ \\
\hline 12087 & 46 & $\delta$ & Acute heart failure & $5.5 \pm 0.7$ \\
\hline 12089 & 46 & t & Bleeding to death & $6.2 \pm 0.5$ \\
\hline 12090 & 31 & 우 & $\begin{array}{l}\text { Death of sleeping draught (Bromvaleryl- } \\
\text { urea) }\end{array}$ & $6.3 \pm 0.5$ \\
\hline 12167 & 45 & $\delta$ & Subdural hemorrhage & $3.6 \pm 1.4$ \\
\hline 12169 & 72 & 오 & Yellow phosphor poisoning & $7.2 \pm 1.1$ \\
\hline 12179 & 56 & $\delta$ & Heart failure & $4.5 \pm 0.9$ \\
\hline 12181 & 48 & $\delta$ & Cerebral compression & $5.0 \pm 0.6$ \\
\hline Mean & & & & $6.2 \pm 1.4$ \\
\hline
\end{tabular}

total amount or part of the ashes was taken in the stainless steel dishes, dried up with infra-red lamp after the addition of distilled water for uniform distribution of the ashes in the dishes. Ash thickness of samples was $34 \pm 17 \mathrm{mg} / \mathrm{cm}^{2}$. Then radioactivity of ashes was measured by a G-M tube with a $2.9 \mathrm{mg} / \mathrm{cm}^{2}$ mica window manufactured by the Scientific Research Institute and "Autoscaler SC-1b" by the Tracerlab: Co. The samples were placed on the first shelf (distance: $1 \mathrm{~cm}$ ) of a sample holder, and 1024 counts were taken for each sample. In no case self-absorption was corrected.

\section{RESUlts AND Discussion}

The weight of organs used was $23.6 \pm 7.9 \mathrm{~g}$ and the amounts of ashes obtained from spleens, brains, livers, kidneys, hearts and lungs were $1.01 \pm 0.20 \%, 1.32 \pm$ $0.14 \%, 1.04 \pm 0.18 \%, 0.91 \pm 0.16 \%, 0.95 \pm 0.23 \%$, and $0.88 \pm 0.21 \%$ of wet weights respectively. The actual values of radioactivity (cpm) per $10 \mathrm{~g}$ wet weight by each organ as well as the cause of death were presented in Table 1.

The measurement was also performed on 21 samples of the sternum, in which the weight of organ was $10.2 \pm 3.9 \mathrm{~g}$, the ash obtained was $13.78 \pm 3.81 \%$ of wet weight and the radioactivity per $10 \mathrm{~g}$ wet weight was $3.3 \pm 3.4 \mathrm{cpm}$. But, 
of human organs

\begin{tabular}{|c|c|c|c|c|}
\hline \multicolumn{4}{|c|}{ Radioactivity per $10 \mathrm{~g}$ of organs (cpm) } & \multirow[b]{2}{*}{ Lung } \\
\hline Brain & Liver & Kidney & Heart & \\
\hline- & $6.6 \pm 0.8$ & - & - & $1.5 \pm 0.7$ \\
\hline $8.0 \pm 0.8$ & $3.3 \pm 0.9$ & $5.2 \pm 0.9$ & - & $1.2 \pm 1.2$ \\
\hline- & - & $5.0 \pm 0.9$ & - & $6.0 \pm 1.3$ \\
\hline- & - & - & - & $1.0 \pm 0.5$ \\
\hline- & $3.0 \pm 0.5$ & $3.4 \pm 0.6$ & $4.1 \pm 1.2$ & $4.2 \pm 1.1$ \\
\hline - & $6.8 \pm 0.9$ & $4.1 \pm 1.3$ & $5.1 \pm 0.8$ & - \\
\hline $7.4 \pm 0.6$ & $5.6 \pm 0.7$ & $3.9 \pm 0.7$ & $4.7 \pm 0.7$ & $5.5 \pm 0.8$ \\
\hline- & $4.9 \pm 0.5$ & $5.8 \pm 1.0$ & - & - \\
\hline $4.4 \pm 0.6$ & $4.7 \pm 0.5$ & $4.5 \pm 1.0$ & - & $4.5 \pm 0.8$ \\
\hline- & $8.7 \pm 0.6$ & $3.4 \pm 0.3$ & $6.2 \pm 0.6$ & - \\
\hline $7.8 \pm 0.9$ & $4.9 \pm 0.6$ & $8.9 \pm 0.7$ & $3.8 \pm 0.7$ & $1.4 \pm 0.6$ \\
\hline- & - & $3.0 \pm 0.4$ & $4.5 \pm 0.5$ & - \\
\hline $4.1 \pm 0.4$ & $3.0 \pm 0.4$ & $2.8 \pm 0.6$ & $5.3 \pm 1.0$ & $4.0 \pm 0.7$ \\
\hline $6.4 \pm 0.6$ & $3.6 \pm 0.4$ & $4.6 \pm 0.6$ & - & $3.6 \pm 0.6$ \\
\hline $3.3 \pm 0.7$ & $3.3 \pm 0.8$ & $2.3 \pm 0.9$ & $2.6 \pm 0.8$ & - \\
\hline $5.1 \pm 0.6$ & $5.5 \pm 0.5$ & $3.9 \pm 0.7$ & $5.7 \pm 0.9$ & $1.6 \pm 1.6$ \\
\hline $6.0 \pm 0.5$ & $7.1 \pm 1.0$ & $1.9 \pm 0.6$ & $5.8 \pm 0.8$ & $2.1 \pm 0.7$ \\
\hline $8.1 \pm 1.0$ & $4.0 \pm 0.6$ & $4.1 \pm 0.6$ & $4.1 \pm 0.6$ & $3.0 \pm 1.0$ \\
\hline $5.2 \pm 0.5$ & $3.7 \pm 0.8$ & $2.8 \pm 0.7$ & $5.7 \pm 1.0$ & $2.5 \pm 1.5$ \\
\hline $4.5 \pm 0.5$ & $5.3 \pm 1.1$ & $3.6 \pm 1.0$ & $8.0 \pm 0.9$ & $2.1 \pm 0.4$ \\
\hline $5.9 \pm 0.5$ & $6.8 \pm 0.6$ & $4.0 \pm 0.5$ & $3.4 \pm 0.6$ & $2.5 \pm 0.5$ \\
\hline $5.9 \pm 1.4$ & $5.0 \pm 1.7$ & $4.1 \pm 1.4$ & $4.9 \pm 1.4$ & $2.9 \pm 1.5$ \\
\hline
\end{tabular}

Table 2. The comparison between actual values of radioactivity in organs and the values calculated from potassium content in them

\begin{tabular}{lcccc}
\hline \multirow{2}{*}{ Organ } & \multicolumn{2}{c}{ Actual value of radioactivity } & \multicolumn{2}{c}{$\begin{array}{c}\text { Presumptive value of radioac- } \\
\text { tivity due to potassium content }\end{array}$} \\
\cline { 2 - 5 } & $\begin{array}{c}\text { Number of } \\
\text { cases }\end{array}$ & $\begin{array}{c}\text { cpm/10 g of } \\
\text { wet weight }\end{array}$ & $\begin{array}{c}\text { Number of } \\
\text { cases }\end{array}$ & $\begin{array}{c}\text { cpm/10 } \text { gof } \\
\text { wet }\end{array}$ \\
\hline Spleen & 19 & $6.2 \pm 1.4$ & 12 & 5.0 \\
Brain & 13 & $5.9 \pm 1.4$ & 12 & $6: 0$ \\
Liver & 18 & $5.0 \pm 1.7$ & 10 & 4.4 \\
Heart & 14 & $4.9 \pm 1.4$ & 10 & 5.0 \\
Kidney & 19 & $4.1 \pm 1.4$ & 12 & 3.3 \\
Lung & 16 & $2.9 \pm 1.5$ & 10 & 3.1 \\
\hline
\end{tabular}

perhaps owing to the high content of calcium, some samples showed the radioactivity under background and some gave large error of measurement, so that the value was not included in Table 1 . 


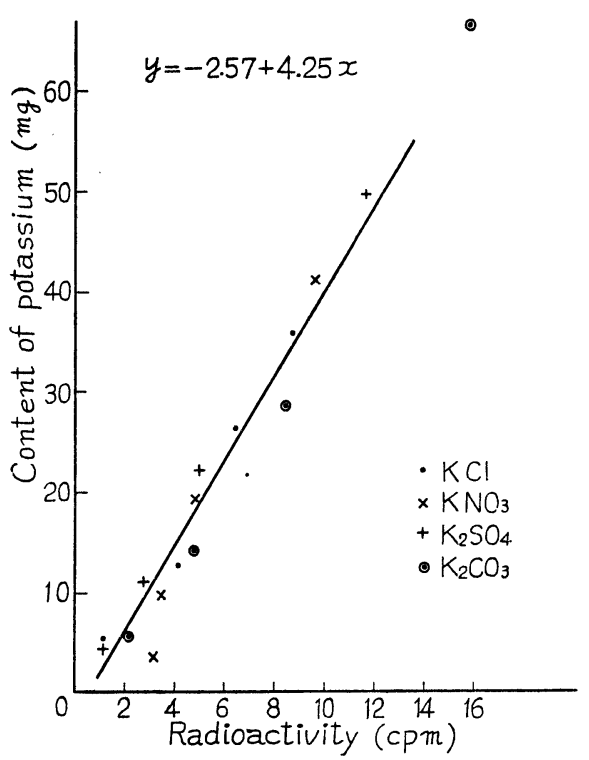

Fig. 1. Radioactivity of K-compounds (Isotope Lab., NIH)

The right column of Table 2 is the presumptive values of radioactivity due to the potassium contained in the organs. These values were obtained by the use of Fig. 1 indicating the relationship between the amount of potassium and radioactivity, which was compiled from the results by the same apparatus on four known inorganic K-compounds.

On the other hand, the radioactivity of $\mathrm{K}^{40}$ per $1 \mathrm{mg}$ is $2 \times 10^{4}$ disintegrations per minute, computing from the half life of it $\left(1.2 \times 10^{9}\right.$ year $)$. The weight of ashes in the organs is roughly $1 \%$ of wet weight as described above, the potassium content of the ashes is about $15 \%$ as shown in the following report by Ohtsu, so $\mathrm{K}^{40}$ in an organ of $10 \mathrm{~g}$ wet weight is $1.5 \times 10^{-3} \mathrm{mg}$ or so. If the efficiency of the counter is $10 \%$, the activity in $10 \mathrm{~g}$ of an organ should be several counts per minute. Thus the value is also coincided with the mean value in Table 2.

\section{Conclusion}

The radioactivity of various organs on about twenty cases of sudden death, was measured which may show the standard or so-called normal values in Japanese towards the second half of the year 1954.

Practically the radioactivity of organs reported in the above are considered to be attributed to the natural radioactive potassium in them.

The authors wish to express their thanks to Dr. Reishi Mizuno, the former Director and Dr. Masayoshi Sugai, Director of the Tokyo-to Medical Examiner's Office for offer of the human organs and to Messers. M. Izawa and T. Kawabata of this Institute for the advice on measurement. 